DOI: $10.15276 /$ ETR.02.2020.5

DOI: $10.5281 /$ zenodo.3976862

UDC: $330.3: 332.1: 504: 658: 382.3$

JEL: O018, Q200

\title{
THREATS DIAGNOSIS OF SUSTAINABLE DEVELOPMENT OF THE UKRAINIAN BLACK SEA COASTAL AREA TERRITORY
}

\section{ДІАГНОСТИКА ЗАГРОЗ СТАЛОМУ РОЗВИТКУ ТЕРИТОРІЇ УКРАЇНСЬКОГО ПРИЧОРНОМОР'Я}

Vitaliy I. Zakharchenko, Doctor of Economics, Professor ORCID: 0000-0003-2903-2471

E-mail: kafedra@mzeid.com

Anastasiia V. Manicheva ORCID: 0000-0002-4560-5703

E-mail: manicheva_av@ukr.net

Received 13.01.2020

Захарченко В.І., Манічева А.В. Діагностика загроз сталому розвитку

На основі проведеної діагностики еколого-економічного стану причорноморських регіонів визначена напруженість економічно ситуації, необхідні параметри іiі оцінки, що дозволяє з науково обгрунтованих позицій приступити до формування регіональної стратегії сталого розвитку. Так для оцінки якості поверхневих вод введено індекс забрудненості вод і наведена його градація.

В методологічному плані автори продовжують використовувати поняття екологічного боргу, як накопичених відходів в результаті виробничої діяльності і зміни навколишнього середовища. Надано використання цього поняття для інтерпретації кредитування економічного розвитку за рахунок відповідного амортизаційного фонду.

Перехід економіки регіонів на модель стійкого розвитку означає забезпечення стійкості економічного зростання при зберіганні стійкого стану навколишнього середовища, а також його зберігання в межах стандартів та їх відновлення при втраті локальними природними комплексами здатності до самоочищення. гроза

Zakharchenko V.I., Manicheva A.V. Threats Diagnosis of Sustainable Development of the Ukrainian Black Sea Coastal Area Territory. Analytical article.

On the basis of the conducted diagnostics of ecological and economic condition of the Black Sea costal area regions the power of the economic situation, necessary parameters of its estimation that allows to start the regional strategy formation of sustainable development from scientifically substantiated positions is defined. Thus, to assess the quality of surface water, the water pollution index is introduced and its gradation is given.

Methodologically, the authors continue to use the concept of environmental debt as an accumulated waste in the result of production activities and environmental changes. Using this concept for the interpretation of crediting the economic development at the expense of the corresponding amortization fund is given.

The regional economy transition to the sustainable development model means ensuring the sustainability of economic growth while maintaining a steady-state condition of the environment, as well as its preservation within standards and their restoration in the loss of local natural complexes ability to self-clean.

Keywords: sustainability, strategy, region, model, risk, debt, threat

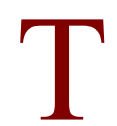

he high level of scientific, technological and socio-economic development in modern society poses a real threat to its existence. This is due to the intensive environment destruction. According to the predictions of the Club of Rome scientists, with the existing trends preservation in the interaction of society and the environment in 35 - 40 years, a mass extinction of the world population is possible, and about 10 countries will own quality drinking water. At the same time, the available resources and economic and technological potential can ensure the life quality at the level of the USA population only for $18 \%$ of the population, and this is the case if the rest, i.e. $82 \%$ of the population will not receive anything. [14, p. 97].

Against these processes background, the environmental state of Ukraine and its regions continues to deteriorate and does not fully depend on the pace of economic change. The main reason is lag influence of the economy on the ecological parameters of territorial subdivisions.

The implementation of the sustainable development principles, which were adopted in 1992, has been carried out through the effective strategy formation. For its development it is necessary to substantiate the means of regulating the behavior of economic entities and territorial subdivisions, which are the tool for creating motivation for environmental protection.

Violations of environmental legislation should be monitored by the State Environmental Inspectorate of Ukraine (SEIU). Meanwhile, the Global Alliance for Health and Pollution (GAHP) has ranked Ukraine fourth among European countries in the number of deaths due to the environmental pollution. Due to the unsatisfactory environmental situation in the country, 57,258 people die annually (hereinafter: www.2000.ua from 31.01.2020). According to 
Ukrainian health professionals and environmentalists, these figures are underestimated. In fact, death rate is almost one and a half times higher.

The main causes of death rate are gas-polluted air and water pollution. In 2019, more than 2 billion cubic meters of sewage were dumped into domestic reservoirs from which we take drinking water, a third of them was untreated or insufficiently treated.

The health professionals claim that $37 \%$ of all cancers are caused by using poor quality drinking water. According to the study carried out by the World Bank, Ukraine ranks 125th out of 180 countries in terms of drinking water per capita. Our country stands between Chad and Sudan. And the situation is much worse in the arid Kherson region.

Internet services show that there is critical air pollution in Ukraine. CO emissions are recorded over the entire territory of Ukraine, only in the western regions they are much less. The carbon monoxide concentration over almost the entire territory of Ukraine is comparable to the industrial areas of China and exceeds the figures throughout Europe.

\section{The analysis of recent researches and publications}

Methodological and practical bases of the investigation of certain territories' environmental condition was studied and analyzed by following scientists in their works: I. Aleksandrov [1], B. Burkynskyi and the researchers of his institute [7], K. Hofman [2], L. Hryniv [3], B. Danylyshyn [4], V. Danylov-Danilnia [5], V. Dyrda and V.Osypenko, O. Pchelintsev [8], E. Riumina [2; 9], A. Tatarkin and the researchers of his institute [10], A.Shapar [13].

Forming the Strategy of Ukraine's transition to sustainable development, a group of scientists insists that such a "Strategy summarizes the approaches to its construction, strategic goals, tactical actions, resource potential, implementation mechanisms, expected results and indicators of their measurement in sectoral and spatial representation" $[7$, p. 630]; and also add that it is "...a predictable model of economic, environmental and social development of the state.. " [7, p. 630]. I. Aleksandrov proposes: "A region's sustainable development strategy is a set of long-term guidelines and goals, practical actions that take into account the characteristic socio-economic, historical, cultural and demographic features of a particular administrative-territorial entity, and methods of monitoring the approach to balanced social, economic and environmental development, which does not violate the regenerative capacity limits of the environment" [1, p. 181]. O. Pchelintsev emphasizes: "It is with the region that the synthesis of efficiency and balance is connected, which forms the sustainable development essence" [8, p. 205].

\section{Unsolved aspects of the problem}

The term, appeared in the last quarter of the twentieth century - "a sustainable development model" of the economic system - replaced the previously existing notions of mandatory protection and environmental protection in the economic activity process. Thus, two components of the new concept are revealed - the preservation of the environment stable-state condition and the stability of the economic system itself as a management object. Intrinsically the sustainable development concept should have an economic component. So, the methodology for studying the transition conditions of the region's economy to the sustainable development model should have a clear quantitative certainty - the environmental component [9, p. 126].

O. Pchelintsev points out: when working with regions, one should always keep in mind their dual nature. On the one hand, these are multidimensional, ecological, socio-economic structures, in principle, which allow and are subject only to interdisciplinary research. On the other hand, regions are chains of the economy spatial structure, i.e. a special type of economic systems that arises on the basis of the interconnected development of production, population and resource sphere. [8, p. 24]. Probably, the words "spatial" and "territorial" should be used as synonyms, deviating from the associated geometric understanding of the three- or, conversely, twodimensionality of socio-economic space.

In addition to the methodological issues, to which we will return, in the process of studying the sustainable development aspects there are points concerning the methodology for determining and refining individual indicators. According to environmentalists' observations in 2018, a very high level of pollution was observed in Mariupol and the Dnieper; the high one - in Odessa, Kyiv, Kryvyi Rih, Lutsk, Mykolayiv, Sloviansk, Kramatorsk, Rubezhnoye, Lviv, Zaporizhia, Lysychansk, Kherson, and Kremenchug. These cities were included in the dissaproval rating due to the high content of harmful substances, including formaldehyde, phenol, hydrogen fluoride, ammonia, as well as due to pollutants of nitrogen dioxide and carbon monoxide. For such estimates, the air pollution index in Ukraine is compiled by five main pollutants: dust, nitrogen and sulfur dioxides, formaldehyde and carbon monoxide. They cause inflammatoty processes, blood clots, inflammation of the vascular walls - just this can be one of the causes of heart attacks and strokes. According to the Ministry of Health of Ukraine, in $2018,78 \%$ of premature deaths were provoked by air pollution (www.2000.ua from 31.01.2020).

Excessive car emissions, chemical and metallurgical plants that save on cleaning filters - all this makes the air toxic smog. Especially suffer children and people with various pulmonary diseases. According to the United Nations, about 7 million people worldwide die each year from diseases from emissions into the atmosphere. In Ukraine, $8 \%$ of deaths are due to exposure to polluted air - about 45 thousand Ukrainians per year.

The problem is that Ukrainians do not receive only adequate material values from using natural resources that belong to them in accordance with the Constitution, but also lose their health. Using some natural resources is illegal - for example, amber, forests, and aquatic bioresources. The amount of losses from illegal logging in 2015-2018 increased by $30 \%$, i.e. to 498.3 million UAH. Illegal catch of 
aquatic living resources exceeded the official and it is 100 thousand tons per year. If the current policy is not changed, the problem will sharpen, as Ukrainians will continue to lose at least UAH 251.57 billion UAH annually, and the environmental condition will only get worse.

In order to live in harmony with the environment, we need a professional and effective SEIU.

\section{The problem statement}

There is an urgent need to identify the main threats to sustainable development of the Ukrainian Black Sea coastal area, to clarify the parameters of this development for the formation of scientific-based regional policies / strategies / programmes to stop the natural ecosystems degradation and ensure a high level and life quality for current and future generations.

\section{The main part}

In terms of the anthropogenic system trinity "human being - habitat - human activity in the direction of the material spiritual goods formation", we should pay attention to the antipode of this system - risk factors are anthropogenic, environmental and man-made [6, p. 5].

The anthropogenic growth factors. These include uncontrolled population growth. The Black sea coastal area is more characterized by migration from «hot spots» (CIS countries, Asia, Africa) and changes in the population's quality (Table 1).

Table 1. Population's migration in the Ukrainian Black Sea coastal area regions in 2016, people

\begin{tabular}{|l|c|c|c|c|}
\hline \multirow{2}{*}{ Region (area) } & \multicolumn{2}{|c|}{ Interstate migration } & \multicolumn{2}{c|}{ Interregional migration } \\
\cline { 2 - 5 } & Increment & Decline & Increment & Decline \\
\hline Mykolaiv & +580 & - & - & -1379 \\
\hline Odessa & +3248 & - & +2533 & - \\
\hline Kherson & +228 & - & - & -2145 \\
\hline
\end{tabular}

Source: compiled by autors on materials [12, p. 326].

In the Odessa region, interstate and interregional migration has an increment mainly in the Black Sea regions / cities (Table 2), which have a more developed infrastructure, as well as in cities with developed production (Kotovsk, Teplodar) [11, p. 331].

Table 2. The population's migration in separate areas of the Odessa region, people

\begin{tabular}{|l|c|c|}
\hline City /region & $\begin{array}{c}\text { Interstate migration: increment, } \\
\text { decline }\end{array}$ & Interstate migration: increment decline \\
\hline Belgorod-Dniester & +105 & +27 \\
\hline Illichivsk & +106 & +290 \\
\hline Kotovsk & +34 & +29 \\
\hline Yuzhne & +70 & +261 \\
\hline Belgorod-Dniester region & +103 & +52 \\
\hline Kominternovo region & +69 & +77 \\
\hline Ovidiopol region & +126 & +193 \\
\hline
\end{tabular}

Source: compiled by autors on materials [11, p. 331]

Also, these risk factors include anthropogenic pressure on the biosphere (the areas reduction that are suitable for the existence of living organisms as a result of both natural disasters and «targeted» human activity).

The environmental risk factors. This is the probability and consequences of accidents, catastrophes and disasters. Modern crises are usually the result of uncontrolled interaction with the environment. In other words, it is doubtful to save work and energy at the same time, as these two processes are incompatible. The possibilities of STP are not exaustible, the more environmental constraints can serve as a barrier to productivity growth and the feasibility of implementing a STP measure .

The technological risk factors. The most pressing challenge is to ensure the safety of people and the environment, especially the equipment of complex machine systems and unique structures. Particularly vulnerable to accidents and catastrophes in the Black Sea coastal area are not even any technological facilities, but individual areas. This is not about the Ukrainian Black Sea region as a whole.

The existence of such a relationship between natural, environmental and technical disasters, the complex impact of threats to the economic security of the Ukrainian Black Sea coastal area (the Odessa, Mykolaiv, Kherson regions are areas with pre-crisis economic situation) determine the policy and strategy of economic complex development of this economic region.

The transition of the region's economy to the sustainable development model to ensure the economic growth sustainability(we understand it as the growth of real non-productive consumption and accumulation) while maintaining a stable state-state condition of the environment. The latter means the natural environment preservation within the limits of the standards and their restoration if local natural complexes lose the ability to clean themselves. 
The tables 3-5 show the data that characterize the dynamics of economic and environmental indicators of the Ukrainian Black Sea coastal area regions in 2010-2016.

Table 3. Air Pollutants Emissions in the Ukrainian Black Sea Coastal Area Regions

\begin{tabular}{|l|c|c|c|c|c|c|c|c|}
\hline \multirow{2}{*}{ Region } & \multicolumn{4}{|c|}{ Total, thousand, tonnes } & \multicolumn{4}{c|}{ Per sq km, tonnes } \\
\cline { 2 - 9 } & 2010 & 2014 & 2015 & 2016 & 2010 & 2014 & 2015 & 2016 \\
\hline Mykolaiv & 71.4 & 83.2 & 87.1 & 83.0 & 2.9 & 3.4 & 3.5 & 3.4 \\
\hline Odessa & 141.1 & 181.2 & 169.0 & 164.8 & 4.2 & 5.4 & 5.1 & 4.9 \\
\hline Kherson & 62.6 & 74.2 & 73.6 & 72.7 & 2.2 & 2.6 & 2.6 & 2.6 \\
\hline
\end{tabular}

Source: compiled by autors on materials [12, p. 484]

Table 4. Wastes Generation in the of the Ukrainian Black Sea Coastal Area Regions, tonnes

\begin{tabular}{|l|c|c|c|c|c|c|}
\hline \multirow{2}{*}{ Region } & \multicolumn{2}{|c|}{2014} & \multicolumn{2}{c|}{2015} & \multicolumn{2}{c|}{2016} \\
\cline { 2 - 7 } & $\begin{array}{c}\text { I-IV hazard } \\
\text { classes }\end{array}$ & $\begin{array}{c}\text { including I- } \\
\text { III hazard } \\
\text { classes }\end{array}$ & $\begin{array}{c}\text { I-IV hazard } \\
\text { classes }\end{array}$ & $\begin{array}{c}\text { including I- } \\
\text { III hazard } \\
\text { classes }\end{array}$ & $\begin{array}{c}\text { I-IV hazard } \\
\text { classes }\end{array}$ & $\begin{array}{c}\text { Including I- III } \\
\text { hazard classes }\end{array}$ \\
\hline Mykolaiv & 3126.9 & 188.8 & 2475.1 & 187.5 & 2476.3 & 152.0 \\
\hline Odessa & 514.0 & 7.5 & 1337.2 & 8.3 & 720.5 & 10.6 \\
\hline Kherson & 439.1 & 86.1 & 485.6 & 105.8 & 439.4 & 90.4 \\
\hline
\end{tabular}

Source: compiled by autors on materials [12, p. 494].

Table 5. Industrial Products Indices in the Ukrainian Black Sea Coastal Area regions, \%

\begin{tabular}{|l|c|c|c|c|}
\hline Region & 2013 & 2014 & 2015 & 2016 \\
\hline Mykolaiv & 110.3 & 104.3 & 99.5 & 96.5 \\
\hline Odessa & 102.9 & 83.6 & 96.9 & 100.6 \\
\hline Kherson & 100.5 & 93.1 & 104.7 & 92.4 \\
\hline
\end{tabular}

Source: compiled by autors on materials [12, p. 97]

The represented data show that it is not necessary to claim the sustainable development of these territorial subdivisions, as the relative production growth is not only accompanied by a reduction in pollution, but also occurs while maintaining or even increasing emissions and toxic waste storage. (Note: hazardous wastes - are wastes that have physical, chemical, biological or other hazardous properties that create or may create a significant hazard to the environment and human health and the means of handling them).

The hazardous wastes contain the following substances that have hazardous properties: toxicity, explosiveness, flammability, high reactivity, or contain agents of infectious deseases [12, p. 477].

The problematics study of the regional economic complex transition to the sustainable development model in the researched period involves finding acceptable limits (threshold level) parameters of economic policy, which is carried out by the territorial administrations and by identifying the areas boundaries of special conditions of the economic complex. Under the latter we will understand such conditions, the sustainable development of which becomes impossible. It means that a significant decline in real non-productive consumption and the accumulation of its potential in the future cannot be avoided, due to the forced higher costs for restoration and maintenance of natural complexes.

The assessment of the natural complexes condition is associated with a number of methodological difficulties: although its search continues for a long time both in our country and abroad. There is not any standard practice yet.

The approach to the relations regulation between society and nature by analogy with the monetary relations between economic entities deserves some attention [2].

The authors of the cited work introduce the concept of environmental debt (ED): these are accumulated changes in the environment as a result of industrial viability. If the result of the condition of environmental protection improves, this circumstance is interpreted as the payment of part of the environmental debt.

In the result of economic activity, wastes are generated, part of which are neutralized in the production process. The expenditures on neutralizing them reduce profits and are taken into account in existing statistics.

The second part of industrial wastes is released into the environment and degrades its environmental parameters. There is an increase in the EB. At a certain stage, the presence of ED affects the regional economy indirectly and the compensation of related economic losses is insignificant. However, sooner or later the degradation of the environment will reach a catastrophic level, which will cause a landslide decline in the economic efficiency of falling living standards. That is why it is necessary to economically assess the ED annual growth and adjust its value to the performance of the region's economy. 
If the gross domestic product of the region adjusted by the amount of ED growth is reduced, it is a sign of a collapsing economy; the gross domestic product growth is achieved due to greater damage to the region's ecology, i.e. by obtaining credit from future generations. The most threatening management option is to reduce the gross domestic product with constant or growing damage to the region's nature.

The situation when there is a simultaneous ED economic growth, can be interpreted as crediting to economic development due to some natural depreciation fund. Obviously, these credits should be short-term, because with the ED long-term accumulation, their critical value can be achieved.

Statistical statements contain information on current expenditures for the protection of water resources, air and land from wastes pollution. Since the volumes of pollutant rectification into the natural environment are known, it is possible to estimate the increase in the environmental debt due to the annual emissions of pollutants. The mentioned value is equal to the possible current expenditures of neutralizing pollutants that have actually entered the environment.

The assessment of already accumulated environmental debt is much more difficult. The following approach to the problem solution is offered in the works carried out in IMPEER NASU on the problematics of regional economy sustainable development: the condition of surface water objects can serve as an ED indicator [7, p. 112-115]. Firstly, surface waters are less inertial and respond quickly to all changes in other environments. Secondly, water bodies accumulate pollutants that are released into them, into the soil and air. Thirdly, water is the most important natural resource for productive and nonproductive consumption.

Surface water quality is assessed with the help of the water pollution index (WPI). A scale can be used to compare the quality of water bodies according to the WPI value: very pure - is less than or equal to $0.5 \%$; pure -is from 0.5 to 1.0 ; moderately polluted - is from 1.0 to 3.0; contaminated - is from 3.0 to 6.0 ; dirty - is from 6.0 to 8.0 ; very dirty — is from 8.0 to 10.0 ; extremely dirty — is more than 10.0 .

The following gradations of the WPI as threshold values are offered in the work[10, p. 163]: satisfactory situation - the WPI value is less than 6 ; pre-crisis situation $-6<\mathrm{WPI}<10$; crisis situation - the WPI is more than 10 .

Extremely unfavourable (if not catastrophic) trend of sharp deterioration of sea and fresh water quality was observed in the 1980s (until 1992.). In many water bodies, it moved from the "polluted" or "dirty" class to the "extremely dirty" class. There has been some improvement of the situation since the mid1990s due to declining industrial production, as well as increased precipitation in winter, spring and summer, which has led to a high degree of waste dilution, and cannot be considered as a positive trend.

The main sources of surface water pollution are household and industrial effluents of large cities of the Black Sea coastal area. The analysis results of the environmental component intensity of the threats to the potential development by the regions are presented in the table 6 .

Table 6. The Ecological Situation Tensions in the Ukrainian Black Sea Coastal Area Regions

\begin{tabular}{|l|c|c|c|c|}
\hline Region & $\begin{array}{c}\text { The pollutant emissions } \\
\text { density into the } \\
\text { atmosphere }\end{array}$ & $\begin{array}{c}\text { Proportion of non- } \\
\text { treatment emissions to } \\
\text { the sea / water bodies }\end{array}$ & $\begin{array}{c}\text { Marine / water } \\
\text { bodies emissions } \\
\text { toxicity index }\end{array}$ & $\begin{array}{c}\text { Non-regulatory storage } \\
\text { of toxic waste }\end{array}$ \\
\hline Odessa & pre-crisis condition & pre-crisis condition & crisis & crisis \\
\hline Mykolaiv & relative safety & pre-crisis condition & relative safety & crisis \\
\hline Kherson & relative safety & crisis & pre-crisis condition & relative safety \\
\hline
\end{tabular}

Source: authors' own development

\section{Conclusions}

In conclusion, one should mention that the main threats in the economic sphere of the Ukrainian Black Sea coastal area are: anthropogenic congestion, irrational using the natural resources, further deterioration of the ecological status of water reservoirs, soil pollution associated with the use of chemicals and their rules violation.

Thus, the sustainable development strategies of the Ukrainian Black Sea coastal area regions should be based on the projected model of the state's socioeconomic and environmental development, which in accordance with the global appeal should enter the sustainable development trajectory. The regions will be able to start the practical transition to sustainable development provided that the general macroeconomic situation is stabilized and a certain level of competitiveness of the national economy in the world economic space is achieved. The main problems solution in the regions' sustainable development will be facilitated by the improvement of the regional policy development mechanism, especially with regard to the scientific community involvement in the joint responsibility with the authorities for structural transformations.

The article is prepared within the framework of SRD "creation of a complex of innovation marketing at the regional level" (№ R\&D 0119U000417).

\section{Abstract}

The high level of scientific, technological and socio-economic development in modern society poses a real threat to its existence. This is due to the intense importance of the environment. Against the background of such 
processes, the environmental condition of the Black Sea coastal area regions continues to deteriorate and does not fully depend on the timing of economic change. The main reason is the lag influence of the economy on the economic parameters of territorial subdivisions.

The problem study of the regional economic complex transition to the sustainable development model in the period considered in the article involves finding an acceptable threshold level of economic and environmental policy, which is conducted by the territories administrations and identifying the boundaries of special states of the economic complex. The Ukrainian Black Sea coastal area regions are defined by territories with a pre-crisis economic situation and this determines the development of an appropriate strategy for sustainable development of this economic region.

On the basis of the conducted diagnostics of ecological and economic condition of the Black Sea coastal area regions the tension of the economic situation, necessary parameters of its estimation that allows to start formation of regional strategy of sustainable development from scientifically substantiated positions is defined. Thus, to assess the quality of surface water, an index of water pollution was introduced and its gradation is given.

In methodological terms, the authors continue to use the concept of environmental debt as accumulated wastes as the result of production activities and changes in the environment. Using this concept for the crediting interpretation for economic development at the expense of the corresponding depreciation fund is given.

The region's economy transition to the sustainable development model means ensuring the sustainability of economic growth while maintaining a stable state of the environment, as well as its preservation within standards and their restoration in the loss of local natural complexes ability to self-clean.

The concept of economic debt is used as the accumulation of changes in the environment. The economic debt growth is interpreted in the work as an opportunity to lend to economic development through the natural depreciation fund. The main threats to the sustainable development of the Black Sea coastal area regions are identified, which allows us to start developing a strategy for sustainable development of each region from new positions, stopping the degradation of natural ecosystems and ensuring a high level and life quality.

\section{Список літератури}

1. Александров І.О. та ін. Регіональна стратегія сталого розвитку регіону: монографія. Донецьк: Ноулідж, 2010. 203 с.

2. Гофман К.Г., Рюмина Е.В. «Кредитные отношения» общества и природы. Экономика и математические методы. 1994. Т. 30. Вып. 2. С. 17-32.

3. Гринів Л.С. Екологічно збалансована економіка: проблеми теорії: монографія. Львів: ЛНУ ім. I. Франка, 2001. 240 с.

4. Данилишин Б.М., Шостик Л.Б. Устойчивое развитие в системе природно-ресурсных ограничений: монография. Киев: СОПС Украины НАНУ, 1999. 367 с.

5. Данилов-Данильян В.И., Лосев К.С. Экологический вызов и устойчивое развитие: монография. Москва: Прогресс-Традиция, 2000. 416 с.

6. Дырда В.И, Осипенко В.П. Устойчивое развитие и проблемы глобальной безопасности. Проблемы безопасности при чрезвычайных ситуациях. Москва: ВИНИТИ. 1995. Вып. 12. С. 332.

7. Наукові засади розробки стратегії сталого розвитку України. Колективна монографія. Одеса: ІПРЕЕД НАНУ, 2012. 714 с.

8. Пчелинцев О.С. Региональная экономика в системе устойчивого развития. Москва: Наука, 2004. $258 \mathrm{c}$.

9. Рюмина Е.В. Концепция экономически устойчивого развития применительно к макроэкономическому уровню. Экономик, математические методы. 1995. Т. 31. Вып. 3. С. 125 135.

10. Социально-экономический потенциал региона: проблемы оценки использования и управления. Под ред. А.И. Татаркина. Екатеринбург: ИЭ Уро РАН, 1997. 205 с.

11. Статистичний щорічник Одеської області за 2016 рік. Одеса: Головне управління статистики в Одеській області, 2017. 549 с.

12. Статистичний щорічник України за 2016 рік. Київ: Державна служба статистики України, 2017. $533 \mathrm{c}$.

13. Стратегія і тактика сталого розвитку. За редакцією А.Т. Шапара. Дніпропетровськ: Моноліт, 2004. $320 \mathrm{c}$.

14. Теоретико-методологічні аспекти підвищення конкурентоспроможності прикордонного регіону: колективна монографія. За редакціє. М.М. Меркулова. Ізмаїл-Одеса: Атлант, 2018. 243 с.

15. Burkynskyi, B., Laiko, O., Talpa, V. (2019). Measures for providing of economic development of the region in conditions of glocalization and decentralization. Economic innovations, 21(2 (71)), 7-18. 


\section{References}

1. Alexandrov I.O. et al. (2010). Regional strategy of sustainable development of the region: monograph. Donetsk: Knowledge [in Ukrainian].

2. Hoffman K.G. \& Ryumina E.V. (1994). "Credit relations" of society and nature. Economics and mathematical methods, 30, Issue. 2, 17-32 [in Russian].

3. Greeniv L.S. (2001). Ecologically balanced economy: problems of theory: monograph. Lviv: LNU named after I. Franka [in Ukrainian].

4. Danilishin B.M. \& Shostik L.B. (1999). Sustainable development in the system of natural resource constraints: a monograph. Kiev: COPS of Ukraine NASU [in Russian].

5. Danilov-Danilyan V.I. \& Losev K.S. (2000). Environmental challenge and sustainable development: a monograph. Moscow: Progress-Tradition [in Russian].

6. Dyrda V.I. \& Osipenko V.P. (1995). Sustainable development and global security issues. Emergency safety issues, 12, 3-32. Moscow: GUILTY [in Russian].

7. (2012). Scientific bases of development of strategy of sustainable development of Ukraine. Collective monograph. Odessa: IPREED NASU [in Ukrainian].

8. Pchelintsev O.S. (2004). Regional economy in the system of sustainable development. Moscow: Nauka [in Russian].

9. Ryumina E.B. (1995). The concept of economically sustainable development in relation to the macroeconomic level. Economics, mathematical methods, 31, Issue. 3, 125-135 [in Russian].

10. (1997). Socio-economic potential of the region: problems of assessment of use and management. A.I. Tatarkina (Ed.). Yekaterinburg: IE UrO RAN [in Russian].

11. (2017). Statistical Yearbook of Odessa region for 2016. Odessa: Main Department of Statistics in Odessa region [in Ukrainian].

12. (2017). Statistical Yearbook of Ukraine for 2016. Kyiv: State Statistics Service of Ukraine [in Ukrainian].

13. (2004). Strategy and tactics of sustainable development. A.T. Shapara (Ed.). Dnepropetrovsk: Monolith [in Ukrainian].

14. (2018). Theoretical and methodological aspects of increasing the competitiveness of the border region: a collective monograph. M.M. Merkulova(Ed.). Izmail-Odessa: Atlant, 2018. 243 p. [in Ukrainian].

15. Burkynskyi, B., Laiko, O., Talpa, V. (2019). Measures for providing of economic development of the region in conditions of glocalization and decentralization. Economic innovations, 21(2 (71)), 7-18.

\section{Посилання на статтю:}

Zakharchenko V.I. Threats Diagnosis of Sustainable Development of the Ukrainian Black Sea Coastal Area Territory / V.I. Zakharchenko, A.V. Manicheva // Економіка: реалї часу. Науковий журнал. - 2020. - № 2 (48). - C. 37-43. - Режим доступу до журн.: https://economics.opu.ua/files/archive/2020/No2/37.pdf. DOI: 10.15276/ETR.02.2020.5. DOI: 10.5281/zenodo.3976862.

\section{Reference a Journal Article:}

Zakharchenko V.I. Threats Diagnosis of Sustainable Development of the Ukrainian Black Sea Coastal Area Territory / V.I. Zakharchenko, A.V. Manicheva // Economics: time realities. Scientific journal. - 2020. - № 2 (48). - P. 37-47. - Retrieved from https://economics.opu.ua/files/archive/2020/No2/37.pdf. DOI: 10.15276/ETR.02.2020.5. DOI: 10.5281/zenodo.3976862. 